\title{
Development of a Project-Based Learning Assessment System to Improve Students' Competence
}

\author{
Wening Patmi Rahayu ${ }^{1}$, Hidayatin ${ }^{1}$, Madziatul Churiyah ${ }^{1}$ \\ ${ }^{1}$ Faculty of Economics, Universitas Negeri Malang, Indonesia
}

\section{Article Info}

Article history:

Received: 15 Januari 2020;

Accepted: 24 March 2020;

Published: 01 October 2020.

\section{Keywords:}

Instrument; Assessment as Learning; Project Based; Competence.

\section{Abstract}

The study aims to develop a project-based learning assessment system to improve students' competence. Data were obtained using the Research and Development (R\&D) methods adopted from Borg \& Gall which comprised of 8 stages. The research products were tested by using the construct and content validations conducted by 2 lecturers and 1 teacher, respectively. Furthermore, students' competence was analyzed by measuring their cognitive, affective and psychomotor domains. The product developed obtained highly valid criteria in the affective, cognitive, and psychomotor domains with scores of $84.6 \%, 84.2 \%$ and $84 \%$, respectively. In addition, the results of content validation obtained highly valid criteria in the affective, cognitive, and psychomotor domains with scores of $90 \%, 93.3 \%$, and $92 \%$. Furthermore, the results of field testing obtained a score of $82 \%$ by 1 archival teacher and $82.77 \%$ by 30 students which showed that the assessment instrument received a good response and feasible for use in learning. The improvement in competence was measured by projects made in the instrument, and it led to a significant improvement in competence before using the assessment as learning instrument.

\begin{tabular}{l} 
Abstrak \\
Studi ini bertujuan untuk mengembangkan sistem penilaian \\
pembelajaran berbasis proyek untuk meningkatkan kompetensi siswa. \\
Data diperoleh dengan menggunakan metode Penelitian dan \\
Pengembangan (R\&D), yang diadopsi dari Borg \& Gall. Produk penelitian \\
diuji dengan menggunakan validasi konstruk dan konten yang dilakukan \\
oleh masing-masing 2 dosen dan 1 guru. Selanjutnya, kompetensi siswa \\
dianalisis dengan mengukur ranah kognitif, afektif, dan psikomotorik \\
mereka. Produk yang dikembangkan memperoleh kriteria yang sangat \\
valid dalam ranah afektif, kognitif, dan psikomotorik dengan skor \\
masing-masing $84,6 \%, 84.2 \%$, dan $84 \%$. Selain itu, hasil validasi konten \\
memperoleh kriteria yang sangat valid dalam ranah afektif, kognitif, dan \\
psikomotorik dengan skor 90\%, 93.3\%, dan 92\%. Selanjutnya, hasil uji \\
lapangan memperoleh skor 82\% oleh 1 guru arsip dan 82.77\% oleh 30 \\
siswa yang menunjukkan bahwa instrumen penilaian menerima respon \\
yang baik dan layak untuk digunakan dalam pembelajaran. Peningkatan \\
kompetensi diukur oleh proyek yang dibuat dalam instrumen, dan itu \\
mengarah pada peningkatan signifikan dalam kompetensi sebelum \\
menggunakan penilaian sebagai instrumen pembelajaran. \\
\hline
\end{tabular}

\section{How to Cite:}

Rahayu, W. P., Hidayatin, H., \& Churiyah, M. (2020). Development of a Project-Based Learning Assessment System to Improve Students' Competence. Jurnal Pendidikan Ekonomi \& Bisnis, 8(2), 86-101. https://doi.org/10.21009/JPEB.008.2.1

* Corresponding Author. 


\section{INTRODUCTION}

In the past 15 years, studies carried out to improve students' competences has experienced significant changes due to the implementation of a project-based assessment system in schools. This method aim to obtain data and information in order to determine students' competence level and learning outcomes, which includes their knowledge, attitudes and skills which ultimately provides feedback (Burke et al. (2016), Craft-Blacksheare \& Frencher (2018), Immonen et al. (2019), Klein \& Fowles (2009), López et al. (2019)).

Assessment is a systematic and continuous process of compiling information concerning students' learning outcomes in order to make decisions based on certain criteria and considerations (Arifin, 2017). With a well-planned assessment, the teacher tends to easily discover the students' level of understanding and help them to achieve their learning goals. Assessment is also defined as an activity designed to employ tools that makes it easier for teachers to determine the materials that has been learned by students and their level of success in the affective, cognitive and psychomotor domains (Kippers et al. (2018), Mulongo \& Amod (2017), Saka (2009), Wanner \& Palmer (2015)). A suitable assessment facilitates an educator in measuring students' learning progress, prepare academic plans and also to determine areas that needs improvement, therefore it is implementation at all levels of education, such as in elementary, vocational, junior and senior high schools.

Vocational high school also abbreviated as SMK, is a form of secondary education that prepares students to be involved in the business and industrial world as well as develop professional attitudes towards work (Anderson Girard et al. (2018), Emir (2013), Korber \& Oesch (2019), Kulpa-Puczyńska (2014), Rahman et al. (2014), and Uzmanoğlu et al. (2010)). SMK have various expertise programs, adjusted to suit the needs of employment and the demands of the community, for strong competencies in the productive field. In contrast to senior high schools (SMA), SMK prioritizes students' skills through the implementation of practical and effectively designed theoretical learning (Emir (2013), Hassall et al. (2005), Kitada \& Harada (2019), PingChen (2011) and Weinstein (2018)). The existence of various learning activities, such as practice and theory, is to determine an assessment tool that needs to be adjusted to the realm.

Competency-based curriculum prioritizes students' skills, attitudes and knowledge that need to be achieved after carrying out certain learning activities (Chan et al. (2017), Eneh et al. (2020), Parson et al. (2018). Furthermore, competence is an explicitly stated goal, that has become the standard in realizing the academic curriculum. Teachers and students need to understand that it is required to achieve and ease learning strategies and indicators of success.

According to Sanjaya, 2006 there are several aspects of competency, namely (1) knowledge, students' abilities in the cognitive domain, (2) understanding the intensity of knowledge possessed by each student, (3) the ability to carry out their assignments, (4) good values, behaviors or ethics, (5) understanding a topic, and (6) interests in carrying out an action which is an aspect of competency that tends to motivate students to carry out certain activities.

In accordance with the results from previous studies conducted on several archival subjects in Vocational High School 2 Tuban, it is observed that the assessment of students' competencies is based on the exercises on the worksheet and completion of homeworks. It is further discovered that the teacher often assigned multiple choice or essay questions taken from the guidebook which serves as a reference for assessment. Meanwhile, the psychomotor aspects of students, such as the skills involved in conducting assignments, were not optimally carried out by the teacher.

Therefore, the determination of the final grades of archival subjects tends to employ students' knowledge, in addition to the use of a simple rubric to assess the affective aspects. The assessment of skills is carried out using numbers, while the learning outcomes of this aspect are obtained from the scores assigned to the students' assignments without the support of an evident data or instruments after completion, therefore no obvious assessments was conducted. Subsequently, the feedback based on learning outcomes, aids the teacher to make evaluations for further learning (Anderson Girard et al. (2018), Anderson et al. (2020), Gentrup et al. (2020), Torres et al. (2020), Vattøy (2020), Yu \& Wu (2020)).

The use of a project-based assessment is a learning instrument that helps teachers analyze students objectively. Conversely, conventional assessment is only used to measure their level of 
understanding. The process of assessing students is not only aimed at discovering their learning outcomes, rather it also aids to improve their competencies oriented towards developing and evaluating skills during academic activities. A student's level of competency is measured after conducting all the tasks adjusted to these objectives by the teacher. An effective assessment model for measuring a student's level of competency is the AAL (Assessment As Learning) model (Sudiyanto et al. 2015).

The implementation of the learning component stated above, emphasizes the active role of students by assessing their work either by self or peers and provides feedback that functions as an evaluation in order to improve their outcome in the next assignment (Lee et al. 2019). According to Wijayanti 2014, self and peer assessment is reported to be quite effective in improving learning outcomes and it serves as a useful feedback. In addition, Wuli et al. 2017, stated that it has an influence on academic activities and causes students to be more productive. According to Arifin et al. (2018), self and peer assessment is used by educators as one of the innovations and alternatives in the process of evaluating learning outcomes (Arifin et al.2018).

The aim of providing feedback, is for students to realize their learning outcomes and make amends where necessary. In addition, they are also motivated to further improve their learning outcomes because they tend to realize their mistakes from previous assignments. Another form of assessment is project evaluation which involves planning, collecting, organizing, processing, and presenting data that needs to be completed within a certain period (Arifin, 2017). Project-based assignments enables students to use their knowledge to carry out tasks in accordance with the various contexts based on the indicators of competency achievement. It is also recommended because it helps develop problem solving abilities, as well as the critical and creative thinking skills of students, for example in archiving the maintenance report of an office.

An authentic project-based assessment with a developed approach tend to effectively improve every aspect of students' scientific thinking skills (Wijayanti, 2014). It is a developed instrument in accordance with the basic competencies that executes archive maintenance procedures, in which the psychomotor domain is assessed. In addition, a certain research reported that a project-based performance assessment conducted by utilizing local potentials tends to increase scientific literacy (Hairida \& Junanto, 2018).

According to Mardhiyana (2017), this opinion is supported by statements that show that it also raises the curiosity of scholars. Furthermore, previous studies stated that the lecturer received a positive response from the implementation of project-based learning conducted by students because it creates conditions for self-realization and continuous improvement (Lasauskiene \& Rauduvaite, 2015). In accordance with the description above, it is therefore necessary to develop an explicit and measurable assessment instrument that encompasses the affective, cognitive and psychomotor domains during and after each learning process. The purpose of this research was to produce a project-based assessment tool as a learning instrument to improve students' competencies in vocational high schools.

\section{METHOD}

This study employed the research and development model, which is used to achieve certain results and test the effectiveness of these products (Adedoyin et al. (2020), Basch et al. (2011), Belcher et al. (2019) Cheng et al. (2020), Huang \& Hou (2019), Mason et al. (2019), Stahl et al., (2019). The researchers used this method to develop a project-based assessment which served as a learning instrument in archival subjects.

The test subjects is based on the characteristics of class X which consist of a total of 30 students enrolled in the Office Automation and Management Skill Program (OTKP) 1, Vocational High School 2 Tuban. The class X of OTKP 1 had an active characteristics and quite competitive, therefore it was considered a suitable test subject in the development of this research. Archival materials were also used in this study, in order to implement its maintenance procedures. The instrument used for data collection was a questionnaire, to ensure that the assessment by the validator and the test subjects are directed according to the criteria of the expected product. Four types of questionnaires were employed, namely (1) construct validation, (2) content validation, (3) 
teacher's response concerning the instrument, and (4) students' response concerning their worksheets.

The research and development design used was adapted from the R\&D model by Borg and Gall (2003) which was modified into several stages, namely (1) Preliminary studies, (2) Planning, (3) Product draft development, (4) Product draft validation, (5) Product draft revision, (6) Field test, (7) Test result revision, (8) Final product. The various stages used is stated in Figure 1.

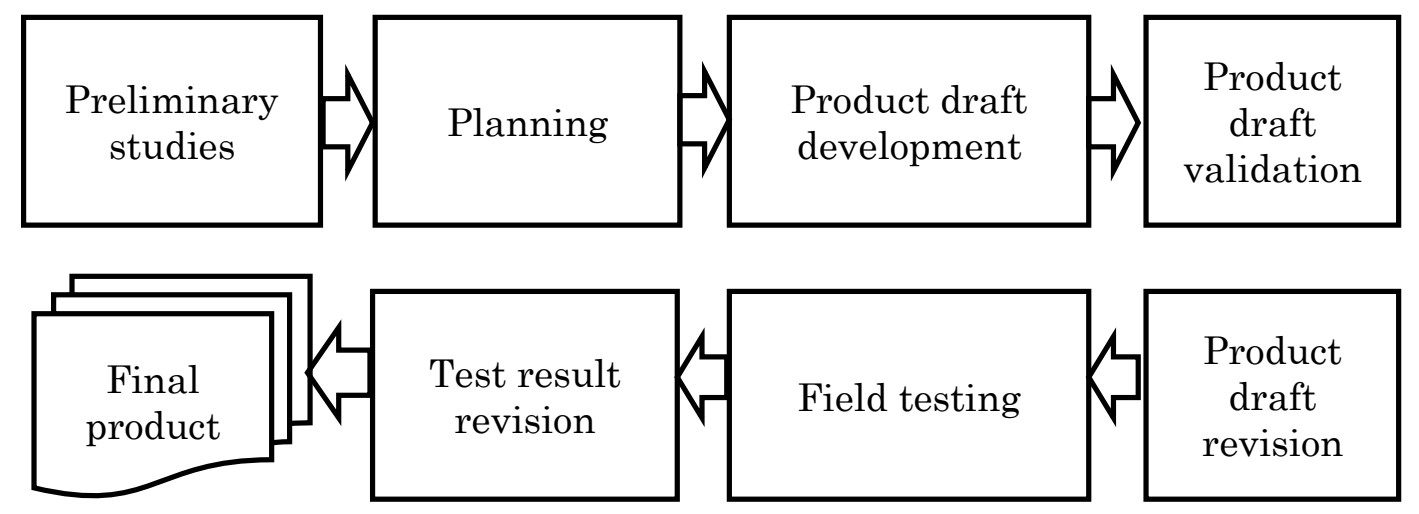

Figure 1. Stages in Research and Development of Project-Based Assessment As Learning Instruments (modified from Borg and Gall, 2003)

The organization of the product draft includes questionnaires preparation which serves as an assessment instrument to evaluate all aspects of students' attitudes by the teacher, students and fellow scholars. Cognitive assessment instrument is in the form of multiple choice and essay questions that needs to be completed based on the instructions. The instrument for psychomotor assessment is in the form of student worksheets (LKS) regarding archive maintenance procedures.

Content and construct validation are activities carried out to determine the feasibility of a product draft from its development research results by comparing it with certain criteria (validation instruments). They are conducted in terms of its content and construct / concept. This was carried out by three validators, two lecturers and a productive teacher that taught archival subjects at Vocational High School 2 for construct and content validation respectively. The process is carried out by giving a questionnaire to the expert validator to determine the feasibility level of the assessment instruments developed. The questionnaire is completed with comments and suggestions to provide input for the improvement of the assessment instrument. The subsequent stage is to carry out the discriminative power test and difficulty level of the items, after which the field testing is conducted.

The discriminative power test and difficulty level of items was carried out on a total of 30 students in class XI of OTKP 1. It was conducted before the implementation of the field test, with the derived data used to determine the discriminative power and the difficulty level of each question in the assessment instrument.

In addition, the difficulty level test was conducted to determine the problems encountered in the research instruments. The formula stated below is used to test the level of difficulty that was encountered in the multiple choice questions (Arikunto, 2015).

Description

$$
\mathrm{P}=\frac{\mathrm{B}}{\mathrm{JS}}
$$

B = number of students that answered the questions correctly

$\mathrm{JS}=$ total number of students below.

The results from the calculations tend to be adjusted to the range of values in table 1 
Table 1. Range of P Values (Difficulty Level)

\begin{tabular}{cc}
\hline Range & Difficulty Level \\
\hline $0.71-1.00$ & Easy \\
$0.31-0.69$ & Medium \\
$0.0-0.30$ & Difficult \\
\hline
\end{tabular}

Source Arikunto, 2015

The discriminative power of items is a test used to differentiate students with high ability from those with low competence. The formula used to calculate it (Arikunto, 2015) is

$$
\mathrm{D}=\frac{\mathrm{B}_{\mathrm{A}}}{\mathrm{J}_{\mathrm{A}}}-\frac{\mathrm{B}_{\mathrm{B}}}{\mathrm{J}_{\mathrm{B}}}=\mathrm{P}_{\mathrm{A}}-\mathrm{P}_{\mathrm{B}}
$$

Description: $\mathrm{D}=$ discriminative power of items

$\mathrm{B}_{\mathrm{A}}=$ number of higher group students that answered the questions correctly

$B_{B}=$ number of lower group students that answered the questions correctly

$\mathrm{J}_{\mathrm{A}}=$ number of higher group students

$\mathrm{J}_{\mathrm{B}}=$ number of lower group students

$\mathrm{P}_{\mathrm{A}}=$ difficulty index of higher group students

$\mathrm{P}_{\mathrm{B}}=$ difficulty index of lower group students below.

The results from the calculations $\mathrm{t}$ tend to be adjusted to the range of values in table 2

Table 2. Range of D Value (Discriminative Power)

\begin{tabular}{cc}
\hline Range & Discriminative Power \\
\hline $0.71-1.00$ & Very Good \\
$0.41-0.70$ & Good \\
$0.21-0.40$ & Enough \\
$0.0-0.20$ & Bad \\
Negative $(-)$ & Very bad, need to be replaced \\
\hline
\end{tabular}

Source adapted from Arikunto, 2015

The technique used to analyze the quantitative data in accordance with the results from the validation assessment, test subjects, and the product draft development is calculated by using the following formula.

$$
\mathrm{V}=\frac{\mathrm{TSe}}{\mathrm{TSh}} \times 100 \%
$$

Description:

$\mathrm{V}=$ validation percentage

TSe $=$ total empirical score

TSh = expected total score

The feasibility level of the product obtained from the research development result is identified by the percentage of the score. The greater the results from the data analysis, the better the feasibility level obtained. The criteria for the feasibility level of the products are stated in table 3. 
Table 3. Feasibility Criteria for Instrument Validation by Validators, Teachers and Student Responses

\begin{tabular}{lll}
\hline No. & \multicolumn{1}{c}{$\begin{array}{c}\text { Validity Criteria } \\
\text { (Competency Test Data) }\end{array}$} & \multicolumn{1}{c}{ Validity Level } \\
\hline 1. & $81 \%-100 \%$ & Very valid, or tends to be used without \\
2. & $61 \%-80 \%$ & revision. \\
3. & $41 \%-60 \%$ & Valid, or needs to be used with little \\
4. & $21 \%-40 \%$ & revision. \\
5. & $0 \%-20 \%$ & Less valid, it is not recommended for \\
& & use because it needs a major revision. \\
& & Invalid, need not be used. \\
& & Very invalid, need not be used. \\
\hline
\end{tabular}

Source Akbar, 2016

Student competencies need to be analyzed after carrying out assignments contained in the instruments ranging from assessment of attitudes, cognitive and psychomotor aspects regarding the archive maintenance. Assuming the average value of the affective, cognitive, and psychomotor domains is above $75.01 \%$ (minimum completeness criteria value), it is therefore stated that the there's an increase in the student's competency. However, when it is below $75.01 \%$, it implies that there is no increase in competency after utilizing the assessment instrument.

An average student's learning outcomes is calculated by using the following formula

$$
N=\frac{\sum x}{\sum x i}
$$

Figure 2. Formula of Learning Outcomes Analysis (Akbar, 2016)

Description:

$\mathrm{N} \quad$ Average score of class

$\Sigma \mathrm{x} \quad$ Total scores of students taking the test

Exi Number of students taking the test

\section{RESULT AND DISCUSSION}

\section{Result from Construct Validation}

The results from the construct validation conducted by two lecturers encompassing aspects of feasibility language, graphics and presentation which include the affective, cognitive and psychomotor domains, is stated in table 4. Meanwhile, qualitative data of the results from the construct validation conducted by the 2 validators is stated in the following table (see table 5).

In accordance with Table 4, the results from the construct validation of the project-based assessment which serves as a learning instrument in archival subjects for 42 items was awarded an average score of 4 by the lecturers. Based on the percentage calculation, it was concluded to be "Very valid" with a score of $84.6 \%, 84.2 \%$, and $84 \%$ in the affective, cognitive, and psychomotor domains, respectively. Meanwhile, the aspects that need to be improved in order to accomplish a perfect assessment instruments that are declared feasible for evaluating learning activities is stated in table 5 .

Table 4. Quantitative Data for the Results of Construct Validation

\begin{tabular}{llcl}
\hline No. & The domains of competence & V & Criteria \\
\hline $\mathbf{1}$ & Affective Domain & 84.6 & Very valid \\
\hline $\mathbf{2}$ & Cognitive Domain & 84.2 & Very valid \\
\hline $\mathbf{3}$ & Psychomotor domain & 84 & Very valid \\
\hline & Average Overall Score & 84.28 & Very valid \\
\hline
\end{tabular}

Source processed by researchers, 2019 
Table 5. Qualitative Data of the Results from the Construct Validation

\begin{tabular}{|c|c|c|}
\hline No. & Validator & Comments and Suggestions \\
\hline 1. & Validator 1. & $\begin{array}{l}\text { - Calculation of the final scores from the } \\
\text { combined multiple choice and essay test needs } \\
\text { to be further explained } \\
\text { - For technical writings, there are some things } \\
\text { that need to be improved, such as } \\
\text { The writing needs to be in reversed form } \\
\text { while filling out the attitude observation } \\
\text { sheet by the teacher. } \\
\text { For the multiple choice questions, answers } \\
\text { need to be in capital letters. }\end{array}$ \\
\hline 2. & Validator 2 & $\begin{array}{l}\text { - This instrument is feasible and needs to be } \\
\text { used. } \\
\text { For the cognitive question grid, the medium } \\
\text { and high level of difficulty needs to be re- } \\
\text { examined. }\end{array}$ \\
\hline
\end{tabular}

Source: processed by researchers, 2019

\section{Results from Content Validation}

Content validation is carried out by an expert validator such as the productive teacher in archival subjects encompassing aspects of feasibility language, content and presentation. The results is shown in the following table.

Table 6. Quantitative Data for the Results from Content Validation

\begin{tabular}{llcl}
\hline No. & \multicolumn{1}{c}{ Indikator Penilaian } & V & Criteria \\
\hline $\mathbf{1}$ & Affective Domain & 90 & Very valid \\
$\mathbf{2}$ & Cognitive Domain & 93.3 & Very valid \\
$\mathbf{3}$ & Psychomotor domain & 92 & Very valid \\
& Average Overall Score & 91.7 & Very valid \\
\hline
\end{tabular}

Source processed by researchers, 2019

The qualitative data for the results from the content validation are stated in table 7 as follows.

Table 7. Qualitative Data for the Results from Content Validation

\begin{tabular}{ccl}
\hline No. $\quad$ Validator & \multicolumn{1}{c}{ Comments and Suggestions } \\
\hline 1. Validator 1 & - & The language used is good and easy to \\
& understand. \\
& The material presented is complete and in \\
& accordance with the BC, however, it is still lacks \\
& illustrative images that makes it contextual. \\
& The instruments used are also good / \\
& appropriate, clear, complete and easy to \\
& understand.
\end{tabular}

Source processed by researchers, 2019

Table 6 shows that the results from the content validation of the project-based assessment which is a learning instrument in archival subjects for 39 items was awarded a maximum score of 5 by the teacher. In accordance with the percentage obtained, it was concluded that the learning instrument in archival subjects is "very valid" with a score of $90 \%, 93.3 \%$, and $91.7 \%$ in the affective, cognitive, and psychomotor domains, respectively. Meanwhile, the aspects that need to be improved in order to achieve a perfect assessment instrument is shown in table 7.

The results from the construct and content validations conducted by the three validators is used as a guide or reference for the improvement of a project-based assessment which serves as a learning instrument in archival subjects before it is tested in the field. 


\section{Product Review of Validation Results}

The suggestions and comments from the validators and the test subject, has made improvements to the project-based assessment which serves as a learning instrument that enhances students' competence in archival subjects. The revision was carried out twice by referring to the suggestions and comments from experts, archival teachers, and students. The reviews of the project-based assessment as a learning instrument in archival subjects is shown in table 8 .

Table 8. Reviews of Project-based Assessment Learning Instrument in Archival Subjects

\begin{tabular}{|c|c|c|c|c|}
\hline No. & $\begin{array}{l}\text { Aspects / } \\
\text { Things }\end{array}$ & $\begin{array}{l}\text { Comments and } \\
\text { Suggestions }\end{array}$ & Before Review & After Review \\
\hline $\mathbf{1}$ & $\begin{array}{l}\text { Scoring } \\
\text { instructions }\end{array}$ & $\begin{array}{l}\text { The calculation of } \\
\text { the final score (a } \\
\text { combination } \\
\text { multiple choice and } \\
\text { essay tests) is } \\
\text { clarified }\end{array}$ & $\begin{array}{l}\text { The calculation of the } \\
\text { final score of the } \\
\text { multiple choice and } \\
\text { essay questions is } \\
\text { less detailed }\end{array}$ & $\begin{array}{l}\text { The calculation of the final } \\
\text { score of multiple choice and } \\
\text { essay questions is detailed }\end{array}$ \\
\hline 2 & $\begin{array}{l}\text { Cognitive } \\
\text { Questions } \\
\text { Grid }\end{array}$ & $\begin{array}{l}\text { - The cognitive } \\
\text { questions grid } \\
\text { is properly } \\
\text { examined to } \\
\text { determine the } \\
\text { level of } \\
\text { difficulty }\end{array}$ & $\begin{array}{l}\text { Some cognitive } \\
\text { questions grids in the } \\
\text { form of multiple } \\
\text { choice and essays are } \\
\text { not in accordance } \\
\text { with the level of } \\
\text { difficulty }\end{array}$ & $\begin{array}{l}\text { The level of difficulty in the } \\
\text { grid of multiple choice and } \\
\text { essay questions has been } \\
\text { adjusted }\end{array}$ \\
\hline 3 & $\begin{array}{l}\text { Technical in } \\
\text { writing }\end{array}$ & $\begin{array}{l}\text { There are } \\
\text { certain things } \\
\text { that need to be } \\
\text { improved in } \\
\text { technical } \\
\text { writing }\end{array}$ & $\begin{array}{l}\text { - The teacher needs } \\
\text { to use reversed } \\
\text { writing in filling } \\
\text { out the attitude } \\
\text { observation sheet } \\
\text { while the answers } \\
\text { for multiple choice } \\
\text { questions, need to } \\
\text { be in capital letters. } \\
\text { - On the student } \\
\text { worksheet, the } \\
\text { writings used were } \\
\text { bold letters that } \\
\text { causes the eyes to } \\
\text { become sore. }\end{array}$ & $\begin{array}{l}\text { - The writing used by the } \\
\text { teacher in filling out the } \\
\text { attitude observation sheet } \\
\text { has been improved while } \\
\text { capital letters is used to } \\
\text { answer multiple choice } \\
\text { questions. } \\
\text { - The student worksheets } \\
\text { have been improved, the } \\
\text { bold letters are only used in } \\
\text { the title }\end{array}$ \\
\hline 4 & $\begin{array}{l}\text { The use of } \\
\text { Images }\end{array}$ & $\begin{array}{l}\text { - Illustrative } \\
\text { images are } \\
\text { lacking in the } \\
\text { summary } \\
\text { material } \\
\text { - The use of } \\
\text { images is not } \\
\text { in accordance } \\
\text { with the level } \\
\text { of education }\end{array}$ & $\begin{array}{l}\text { - Images are } \\
\text { lacking in the } \\
\text { summary } \\
\text { material } \\
\text { - In the project } \\
\text { assessment } \\
\text { sheets and } \\
\text { questions, the } \\
\text { images are not } \\
\text { in accordance } \\
\text { with the level of } \\
\text { education }\end{array}$ & $\begin{array}{l}\text { - Images are included in the } \\
\text { summary material } \\
\text { - The images in the project } \\
\text { assessment sheets and } \\
\text { questions are adjusted to } \\
\text { the level of education }\end{array}$ \\
\hline
\end{tabular}

Source processed by researchers, 2019 


\section{Results from Field Testing \\ Results from Archive Teacher and Student Responses}

The data of the field testing results from this research development was obtained from the test subjects, which consist of one archival teacher and 30 students in class X OTKP 1 , Vocational High School 2 Tuban. Questionnaire responses by teachers and students regarding the assessment produced include aspects of language, suitability of scholar's development, presentation and benefits of instruments, use of images or illustrations.

In the initial stage, the students work on assignments contained in the assessment instruments ranging from aspects of attitude, cognitive and psychomotor. Subsequently, they are given a self and peer assessment questionnaire containing their responses to the student worksheet. Meanwhile, the questionnaire containing the teachers and students' responses concerning the assessment developed include quantitative data obtained from the testing stated.

Table 9. Quantitative Data of the Field Testing Results from Archival Teachers and Students

\begin{tabular}{cccc}
\hline No. & Assessment Indicator & V & Criteria \\
\hline $\mathbf{1}$ & Average Teacher Response Score & 82 & Very valid \\
$\mathbf{2}$ & Average Student Response Score & 82.77 & Very valid \\
\hline
\end{tabular}

Source processed by researchers, 2019

The qualitative data from the testing of archival teacher is stated as follows.

Table 10. Qualitative Data of Field Testing Results from Archival Teacher

\begin{tabular}{lll} 
Respondent & \multicolumn{1}{c}{ Comments and Suggestions } \\
\hline Teacher & - Assessment instrument is simplified \\
& The work steps on each project assignment are more \\
detailed/clarified, therefore it does not cause & confusion/misunderstanding to the students. \\
- & $\begin{array}{l}\text { Work orders need to be made more detailed and } \\
\text { understandable } \\
\text { - Image of project questions is adjusted to the level of } \\
\text { vocational high school }\end{array}$
\end{tabular}

Source processed by researchers, 2019

In accordance with the calculation of percentages carried out, it was concluded that the project-based assessment learning instrument developed to improve competence in archival subjects was declared "Very valid" with a score of $82 \%$ and $82.77 \%$ by teacher and students, respectively. Meanwhile, table 10, shows the aspects that need to be improved in order to enhance the assessment products.

\section{Test Results from Discriminative Power and Difficulty Level of Questions}

Based on the answer sheet of the students in class XI OTKP 1, an analysis to test the discriminative power and difficulty level of the 30 multiple choice question was carried out. In accordance with the calculation for the discriminative power level of the questions, the following classification is shown in table 11.

Table 11. Classification of the discriminative power level of question

\begin{tabular}{ccc}
\hline $\begin{array}{c}\text { Discriminative } \\
\text { Power Level of } \\
\text { question }\end{array}$ & Question Number & Total \\
\hline Good & $1,3,4,6,7,8,9,12,13,14$, & 20 \\
Enough & $17,18,21,22,24,25,26,27,29,30$ & 5 \\
Bad & $2,10,16,19,28$ & 5 \\
\hline
\end{tabular}

Source processed by researchers, 2019 
follows.

Based on the calculation for the difficulty level of the questions, the classification is as Table 12. Classification of the difficulty level of question

\begin{tabular}{lcc}
\hline \multicolumn{1}{c}{ Difficulty Level of Question } & Question Number & Total \\
\hline Easy & $1,2,3,15,29$ & 5 \\
Medium & $4,5,7,9,10,12,13$, & 15 \\
& $14,16,18,19,24,26,27,28$ & \\
Difficult & $6,8,11,17,20,21,22,23,25,30$ & 10 \\
\hline
\end{tabular}

Source processed by researchers, 2019

\section{Results from Student Competence}

To measure the students' competence in the affective domain, an attitude, self and peer assessment instrument in the form of a questionnaire was employed. The questionnaire consists of statements that contain attitudes such as honest, discipline, responsible, care, polite, environmentally friendly, mutual cooperation, peace-loving, responsive, and pro-active. The Modus formula (the score that often appears) was used to calculate the affective score.

Cognitive assessment instrument is in the form of multiple choice and essay questions that are completed based on instructions where each correct and wrong answer is assigned a score of 1 and 0 respectively. In addition, the correct answer for the essay attains a maximum score.

The psychomotor assessment instrument is a student worksheet (LKS) concerning archive maintenance procedures which is completed with rubrics and criteria for project evaluation which consist of aspects of planning, implementation, and reporting. The psychomotor scores is calculated by dividing the acquisition score by the maximum score.

Student competencies are analyzed after they have carried out assignments in accordance with the assessment instruments which includes aspects of attitude, cognitive and psychomotor. The total and average scores obtained by the 30 students in Class X after conducting assignments based on the assessment instrument is stated in table 13.

Table 13. Analysis of Student Competencies

\begin{tabular}{ccc}
\hline Aspect & Total score & Average \\
\hline Affective & 3110 & 86.38 \\
Cognitive & 3215 & 89.30 \\
Psychomotor & 3115 & 86.52 \\
\hline
\end{tabular}

Source processed by researchers, 2019

Based on table 14, the average score in the affective, cognitive, and psychomotor domains is $86.38 \%, 89.30 \%$, and $86.52 \%$, respectively. However, the average score of all domains is above $75.01 \%$.

\section{Discussion}

\section{The Feasible Project-Based Assessment As Learning Instrument}

The project-based assessment developed by researchers as a learning instrument for archival subjects have fulfilled the feasibility criteria, additionally it is used as valid and beneficial tool for evaluating academics. The feasibility criteria are obtained from the construct and content validations as well as teacher and student responses in the questionnaire. Self and peer assessment is one of its component. This means that the assessment instrument tends to be used by the teacher as a guide in preparing other tools for the similar or different subjects. Therefore, as a learning instrument, it becomes an alternative choice for teachers in developing an assessment tool for measuring the students' actual competencies.

A valid, reliable and feasible process is required in producing a project-based assessment 
as learning instruments. This process also needs to be carried out by the teacher in order to produce an instrument that is in accordance with what is required, measurable, understandable, and tends to be used in various avenues to access learning activities and its achievements. Therefore, the objectives of competence, academic activities, and the implementation of assessment is appropriate.

The quality of project-based learning in terms of validity, practicality and effectiveness of students is included in the excellent category (Fatkhurrokhman et al., 2017). This opinion is also strengthened by the research that reports that its tools used in learning are categorized as very valid (Dewi, 2014). Sukmasari \& Rosana (2017), stated that this instrument in accordance with the discovery learning model developed is declared valid and reliable, therefore it is feasible and able to measure students' problem solving skills. In addition, there is also research that states that project-based learning affective assessments are declared valid and reliable for use and tends to improve student learning outcomes during each meeting (Jirana et al., 2017).

The results from the assessment instruments are needed by the teacher to determine the affective, cognitive and psychomotor aspects of students. In addition, feedback affords the teacher the opportunity to realize the students' level of understanding the learning material, in order to make evaluations for further learning. For students, it serves as an evaluation and improvement tool that tends to be used in the next assignments. It is also expected to provide benefits that serves as a guideline in developing assessment instruments in other subjects in Vocational High Schools.

The feasible project-based learning instrument is a relevant choice for Vocational High Schools in carrying out assessments. This is in accordance with the objectives of the school, which is a form of secondary education, that prioritizes the development of students' competencies to be able to carry out a particular job and by preparing scholars to be involved in the business and industrial world as well as develop professional attitudes towards work (Anderson Girard et al. (2018), Emir (2013), Korber \& Oesch (2019), Kulpa-Puczyńska (2014), Rahman et al. (2014), and Uzmanoğlu et al. (2010).

\section{Assessment as Learning Instrument to improve Student Competence}

This study reports that the implementation of assessment as a learning instruments enhances the students' level of competency after conducting assignments contained in the projectbased tool concerning archival maintenance procedures developed from the affective, cognitive and psychomotor domains. These analyses are supported by several research results which stated that the assessment as a learning model tends to improve students' competencies in aspects of attitude, knowledge and skills (Farrell (2020), Lee et al. (2019), Leong et al. (2018), Schuwirth \& van der Vleuten (2019), Sudiyanto et al., (2015).

Assessment is carried out during learning activities and it serves as a guide in evaluating and improving teaching and academic pursuits (Farrell (2020), Fetherston \& Batt (2019), Lee et al. (2019) and Sudiyanto et al. (2015). Teachers that employ assessment as an academic tool tend to provide feedback to students concerning their learning outcomes and they are also able to realize and determine their level of progress. It also involves the implementation of self and peer assessment. In addition, assessment as learning tool also requires students to design procedures, criteria, and rubrics. Therefore, they tend to realize what they need to carry out in order to achieve maximum learning outcomes.

Assessment as an aspect of academics emphasizes on the development and support of the students' metacognition, which implies that they are given the opportunity and guided by monitoring results to improve their learning (Earl (2013), and Lee et al. (2019)). The AAL (assessment as learning) model is effectively used to improve student accounting competence in in Vocational Schools (Farrell (2020), Fetherston \& Batt (2019), Lee et al. (2019), Leong et al. (2018), Schuwirth \& van der Vleuten (2019), Sudiyanto et al. (2015). The five components of the assessment model are as follows: (1) learning objectives, indicators and criteria for success (2) structured learning assignments (3) self-assessment, (4) peer assessment (5) feedback for improved learning (R. Arifin et al., 2018).

The provision of feedback in project-based assessment has a positive impact on learning activities and also develops students' thinking habits (Christensen \& Lynch, 2020; Meir et al., 
2019; Steen-Utheim \& Wittek, 2017; Yu \& Wu, 2020). This is supported by previous research which showed that in relation to mathematics learning outcomes, students' interest in basic statistics courses provide immediate feedback which are higher than those that usually receive delayed response (Seruni \& Hikmah, 2015). In addition, it is also supported by studies which states that the provision of feedback in college is important in order to improve and develop their confidence and communication skills, and also encourages students to become independent learners (Issa et al., 2014).

\section{Conclusions and Suggestions Conclusion}

This research and development produced a project-based assessment that is feasible and tend to improve students' competency. In addition, the instruments developed include assessment in the affective, cognitive and psychomotor domains. Rigorous assessment tool and rubric assisted teachers to realize the actual competency of the students.

\section{Suggestions}

The following are suggestions in accordance with a project-based assessment which serves as learning instruments.

\section{Suggestions for Further Product Development}

The research and development of project-based assessment in archival subjects does not encompass all stages involved in the methods proposed by Borg and Gall. Therefore, in the context for further product development, it was suggested that other researchers need to get to the final phase, of this study namely the dissemination and implementation stages.

\section{Suggestion for Dissemination}

The distribution of the product is carried out through MGMP (Subject Teacher Working Group) in every sub-district, region, and city. In addition, MGMP also collaborates with district education offices by providing trainings and workshops to vocational high school teachers in accordance with the importance of the implementation of a project-based assessment tool. Furthermore, they need to collaborate with publishers to publish and monitor the distribution of project-based assessment as learning instruments in archival subjects.

\section{Suggestion for Use}

The project-based assessment is only used by teachers to evaluate the assignments on archival subjects. In using the instrument, teachers are expected to understand how to utilize it and the available instructions. However, there are still teachers that have not used project-based assessment to teach, therefore they need to develop their personal learning instruments. This is carried out by studying the structure and assessment criteria that have been developed. Teachers use this assessment as a reference and guide in project project-based assessment as learning instruments in other subjects.

\section{REFERENCES}

Adedoyin, F. F., Alola, A. A., \& Bekun, F. V. (2020). An assessment of environmental sustainability corridor: The role of economic expansion and research and development in EU countries. $\begin{array}{llllll}\text { Science of The Total } & \text { Environment, } & 713, & 136726 .\end{array}$ https://doi.org/10.1016/j.scitotenv.2020.136726

Akbar, S. (2016). Instrumen Perangkat Pembelajaran. Bandung: PT Remaja Rosdakarya.

Anderson Girard, T., Russell, K., \& Leyse-Wallace, R. (2018). Academy of Nutrition and Dietetics: Revised 2018 Standards of Practice and Standards of Professional Performance for Registered Dietitian Nutritionists (Competent, Proficient, and Expert) in Mental Health and 
Addictions. Journal of the Academy of Nutrition and Dietetics, 118(10),19751986.e53.https://doi.org/10.1016/j.jand.2018.07.013

Anderson, M. J., Ofshteyn, A., Miller, M., Ammori, J., \& Steinhagen, E. (2020). "Residents as Teachers" Workshop Improves Knowledge, Confidence, and Feedback Skills for General Surgery Residents. Journal of Surgical Education, S1931720420300106. https://doi.org/10.1016/j.jsurg.2020.01.010

Arifin. (2017). Evaluasi Pembelajaran (Prinsip, Teknik, dan Prosedur). Bandung: PT Remaja Rosdakarya.

Arifin, R., Kusumah, I. H., \& Mubarak, I. (2018). Hasil Penilaian Diri Dan Penilaian Teman Sebaya Dibandingkan Dengan Assessment Dosen Untuk Hasil Produk Mata Kuliah Body Otomotif. Journal of Mechanical Engineering Education,5 (1),78. https://doi.org/10.17509/ jmee.v5i1.12623

Arikunto, S. (2015). Dasar-Dasar Evaluasi Pendidikan Edisi 2. Jakarta: PT Bumi Aksara.

Basch, E., Abernethy, A. P., \& Reeve, B. B. (2011). Assuring the Patient Centeredness of PatientReported Outcomes: Content Validity in Medical Product Development and Comparative Effectiveness Research. Value in Health, 14(8), 965-966. https://doi.org/10.1016/j.jval.2011.10.002

Belcher, B. M., Claus, R., Davel, R., \& Ramirez, L. F. (2019). Linking transdisciplinary research characteristics and quality to effectiveness: A comparative analysis of five research-fordevelopment projects. Environmental Science \& Policy, 101, 192-203. https://doi.org/10.1016/j.envsci.2019.08.013

Borg, W. R., \& Gall, R. (2003). Educational Research: An Introduction (7th ed.). New York: Logman Inc.

Burke, E., Kelly, M., Byrne, E., Ui Chiardha, T., Mc Nicholas, M., \& Montgomery, A. (2016). Preceptors' experiences of using a competence assessment tool to assess undergraduate nursing students. Nurse Education in Practice, 17, 8-14. https://doi.org/10.1016/j.nepr.2016.01.004

Chan, C. K. Y., Fong, E. T. Y., Luk, L. Y. Y., \& Ho, R. (2017). A review of literature on challenges in the development and implementation of generic competencies in higher education curriculum. International Journal of Educational Development, 57, 1-10. https://doi.org/10.1016/j.ijedudev.2017.08.010

Cheng, M., Shao, Z., Gao, F., Yang, C., Tong, C., Yang, J., \& Zhang, W. (2020). The effect of research and development on the energy conservation potential of China's manufacturing industry: The case of east region. Journal of Cleaner Production, 258, 120558. https://doi.org/10.1016/j.jclepro.2020.120558

Christensen, M., \& Lynch, J. (2020). Supporting student learning through the use of a sequential case study workbook: An inductive content analysis of student feedback. Nurse Education Today, 104387. https://doi.org/10.1016/j.nedt.2020.104387

Craft-Blacksheare, M., \& Frencher, Y. (2018). Using high fidelity simulation to increase nursing students' clinical postpartum and newborn assessment proficiency: A mixed-methods research study. Nurse Education Today, 71, 198-204. https://doi.org/10.1016/j.nedt.2018.09.031

Dewi, A. (2014). Pengembangan Instrumen Penilaian Psikomotor Pada Materi Sistem Pencernaan Kelas XI SMA. Jurnal Pelangi, 6(2). https://doi.org/10.22202/jp.2014.v6i2.298

Earl, L. M. (2013). Using Classroom Assesment to Maxime Student Learning. California: Corwin Press.

Emir, O. (2013). The Effect of Training on Vocational High School Students in their Professional Development. Procedia-Social and Behavioral Sciences, 106, 2724-2738. https://doi.org/10.1016/j.sbspro.2013.12.313

Eneh, P., Steeb, D. R., Cope, R., Gim, S., Northrop, E. F., Brearley, A. M., \& Okoro, O. (2020). Students' perceptions of global health competencies in the doctor of pharmacy (PharmD) curriculum. Currents in Pharmacy Teaching and Learning, S1877129720300125. https://doi.org/10.1016/j.cptl.2020.01.012 
Farrell, C. (2020). Do international marketing simulations provide an authentic assessment of learning? A student perspective. The International Journal of Management Education, 18(1), 100362. https://doi.org/10.1016/j.ijme.2020.100362

Fatkhurrokhman, M., Permata, E., Ekawati, R., \& Rizal, S. U. (2017). Pengembangan perangkat pembelajaran teknik digital berbasis project based learning di jurusan pendidikan teknik elektro. Jurnal Pendidikan Vokasi, 7(1), 101. https://doi.org/10.21831/jpv.v7i1.12547

Fetherston, C. M., \& Batt, S. (2019). Enhancing student understanding of nursing inherent requirements using assessment for learning. Collegian, S1322769619301167. https://doi.org/10.1016/j.colegn.2019.07.002

Gentrup, S., Lorenz, G., Kristen, C., \& Kogan, I. (2020). Self-fulfilling prophecies in the classroom: Teacher expectations, teacher feedback and student achievement. Learning and Instruction, 66, 101296. https://doi.org/10.1016/j.learninstruc.2019.101296

Hairida, H., \& Junanto, T. (2018). The Effectiveness of Performance Assessment in Project-Based Learning by Utilizing Local Potential to Increase the Science Literacy. International Journal of Pedagogy and Teacher Education, 2, 17. https://doi.org/10.20961/ijpte.v2i0.25722

Hassall, T., Joyce, J., Arquero Montaño, J. L., \& Donoso Anes, J. A. (2005). Priorities for the development of vocational skills in management accountants: A European perspective. Accounting Forum, 29(4), 379-394. https://doi.org/10.1016/j.accfor.2005.03.002

Huang, C.-H., \& Hou, T. C.-T. (2019). Innovation, research and development, and firm profitability in Taiwan: Causality and determinants. International Review of Economics \& Finance, 59, 385-394. https://doi.org/10.1016/j.iref.2018.10.004

Immonen, K., Oikarainen, A., Tomietto, M., Kääriäinen, M., Tuomikoski, A.-M., Kaučič, B. M., Filej, B., Riklikiene, O., Flores Vizcaya-Moreno, M., Perez-Cañaveras, R. M., De Raeve, P., \& Mikkonen, K. (2019). Assessment of nursing students' competence in clinical practice: A systematic review of reviews. International Journal of Nursing Studies, 100, 103414. https://doi.org/10.1016/j.ijnurstu.2019.103414

Issa, T., Issa, T., \& Kommers, P. (2014). Feedback and Learning Support That Fosters Students' Independent Learning: An Australian Case Study. The International Journal of Learning: Annual Review, 19(1), 29-39. https://doi.org/10.18848/1447-9494/CGP/v19/58837

Jirana, J., Tahmir, S., \& Mustami, K. (2017). Pengembangan Assesmen Afektif Pembelajaran Berbasis Proyek Pada Mata Pelajaran Biologi Siswa SMA Negeri 2 Majene. Education and Human Development Journal, 1(1). https://doi.org/10.33086/ehdj.v1i1.286

Kippers, W. B., Wolterinck, C. H. D., Schildkamp, K., Poortman, C. L., \& Visscher, A. J. (2018). Teachers' views on the use of assessment for learning and data-based decision making in classroom practice. Teaching and Teacher Education, 75, 199-213. https://doi.org/10.1016/j.tate.2018.06.015

Kitada, M., \& Harada, J. (2019). Progress or regress on gender equality: The case study of selected transport STEM careers and their vocational education and training in Japan. $\begin{array}{lllll}\text { Transportation Research Interdisciplinary } & \text { Perspectives, } & 100009 .\end{array}$ https://doi.org/10.1016/j.trip.2019.100009

Klein, C. J., \& Fowles, E. R. (2009). An Investigation of Nursing Competence and the Competency Outcomes Performance Assessment Curricular Approach: Senior Students' Self-Reported Perceptions. Journal of Professional Nursing, 25(2), 109-121. https://doi.org/10.1016/j.profnurs.2008.08.006

Korber, M., \& Oesch, D. (2019). Vocational versus general education: Employment and earnings over the life course in Switzerland. Advances in Life Course Research, 40, 1-13. https://doi.org/10.1016/j.alcr.2019.03.003

Kulpa-Puczyńska, A. (2014). Teachers of Polish Vocational Schools vs. Changes in the Model of Employment and Organization of Work. Procedia - Social and Behavioral Sciences, 141, 969 975. https://doi.org/10.1016/j.sbspro.2014.05.166

Lasauskiene, J., \& Rauduvaite, A. (2015). Project-Based Learning at University: Teaching Experiences of Lecturers. Procedia - Social and Behavioral Sciences, 197, 788-792. https://doi.org/10.1016/j.sbspro.2015.07.182 
Lee, I., Mak, P., \& Yuan, R. E. (2019). Assessment as learning in primary writing classrooms: An exploratory study. Studies in Educational Evaluation, 62, 72-81. https://doi.org/10.1016/j.stueduc.2019.04.012

Leong, W. S., Ismail, H., Costa, J. S., \& Tan, H. B. (2018). Assessment for learning research in East Asian countries. Studies in Educational Evaluation, 59, 270-277. https://doi.org/10.1016/j.stueduc.2018.09.005

López, Á. R., Souto, J. E., \& Noblejas, M. L. A. (2019). Improving teaching capacity to increase student achievement: The key role of communication competences in Higher Education. Studies in Educational Evaluation, 60, 205-213. https://doi.org/10.1016/j.stueduc.2018.10.002

Mardhiyana, D. (2017). Upaya Meningkatkan Rasa Ingin Tahu Mahasiswa Melalui Penerapan Pembelajaran Berbasis Proyek Pada Mata Kuliah Evaluasi Proses Dan Hasil Pembelajaran Matematika. Delta: Jurnal Ilmiah Pendidikan Matematika, 5(1), 1. https://doi.org/10.31941/delta.v5i1.389

Mason, M., Crossley, M., \& Bond, T. (2019). Changing modalities in international development and research in education: Conceptual and ethical issues. International Journal of Educational Development, 70, 102080. https://doi.org/10.1016/j.ijedudev.2019.102080

Meir, E., Wendel, D., Pope, D. S., Hsiao, L., Chen, D., \& Kim, K. J. (2019). Are intermediate constraint question formats useful for evaluating student thinking and promoting learning in formative assessments? Computers \& Education, 141, 103606. https://doi.org/10.1016/j.compedu.2019.103606

Mulongo, G., \& Amod, Z. (2017). Participation in cross-national learning assessments and impact on capacity development: Programmes, practice, structures and teacher competency. Case study of Kenya, Tanzania and South Africa. Evaluation and Program Planning, 65, 94-105. https://doi.org/10.1016/j.evalprogplan.2017.07.003

Parson, L., Childs, B., \& Elzie, P. (2018). Using Competency-Based Curriculum Design to Create a Health Professions Education Certificate Program the Meets the Needs of Students, Administrators, Faculty, and Patients. Health Professions Education, 4(3), 207-217. https://doi.org/10.1016/j.hpe.2018.03.008

Ping-Chen, X. (2011). Higher vocational talents training scheme reform research and practice. Procedia Engineering, 15, 4126-4130. https://doi.org/10.1016/j.proeng.2011.08.774

Rahman, A. bt A., Hanafi, N. binti M., Mukhtar, M. bt I., \& Ahmad, J. bin. (2014). Assessment Practices for Competency based Education and Training in Vocational College, Malaysia. Procedia - Social and Behavioral Sciences, 112, 1070-1076. https://doi.org/10.1016/j.sbspro.2014.01.1271

Saka, A. Z. (2009). Hitting two birds with a stone: Assessment of an effective approach in science teaching and improving professional skills of student teachers. Procedia - Social and Behavioral Sciences, 1(1), 1533-1544. https://doi.org/10.1016/j.sbspro.2009.01.270

Sanjaya, W. (2006). Pembelajaran dalam Implementasi Kurikulum Berbasis Kompetensi. Jakarta: Kencana.

Schuwirth, L. W. T., \& van der Vleuten, C. P. M. (2019). How 'Testing' Has Become 'Programmatic Assessment for Learning.' Health Professions Education, 5(3), 177-184. https://doi.org/10.1016/j.hpe.2018.06.005

Seruni, S., \& Hikmah, N. (2015). Pemberian Umpan Balik Dalam Meningkatkan Hasil Belajar dan Minat Belajar Mahasiswa. Formatif: Jurnal Ilmiah Pendidikan MIPA, 4(3). https://doi.org/10.30998/formatif.v4i3.158

Stahl, B. C., Chatfield, K., Ten Holter, C., \& Brem, A. (2019). Ethics in corporate research and development: Can responsible research and innovation approaches aid sustainability? Journal of Cleaner Production, 239, 118044. https://doi.org/10.1016/j.jclepro.2019.118044

Steen-Utheim, A., \& Wittek, A. L. (2017). Dialogic feedback and potentialities for student learning. Learning, Culture and Social Interaction, 15, 18-30. https://doi.org/10.1016/j.lcsi.2017.06.002

Sudiyanto, S., Kartowagiran, B., \& Muhyadi, M. (2015). PENGEMBANGAN MODEL ASSESSMENT AS LEARNING PEMBELAJARAN AKUNTANSI DI SMK. Jurnal 
Penelitian Dan Evaluasi Pendidikan, 199 19-201.

https://doi.org/10.21831/pep.v19i2.5579

Sukmasari, V. P., \& Rosana, D. (2017). Pengembangan penilaian proyek pembelajaran IPA berbasis discovery learning untuk mengukur keterampilan pemecahan masalah. Jurnal Inovasi Pendidikan IPA, 3(1), 101. https://doi.org/10.21831/jipi.v3i1.10468

Torres, J. T., Higheagle Strong, Z., \& Adesope, O. O. (2020). Reflection through assessment: A systematic narrative review of teacher feedback and student self-perception. Studies in Educational Evaluation, 64, 100814. https://doi.org/10.1016/j.stueduc.2019.100814

Uzmanoğlu, S., İşgören, N. Ç., Çınar, A., Tektaş, N., Oral, B., Büyükpehlivan, G., Ulusman, L., Öznaz, D., \& Polat, Z. (2010). Evaluation of educational and technical structure at vocational schools. Procedia - Social and Behavioral Sciences, 2(2), 3447-3451. https://doi.org/10.1016/j.sbspro.2010.03.532

Vattøy, K.-D. (2020). Teachers' beliefs about feedback practice as related to student self-regulation, self-efficacy, and language skills in teaching English as a foreign language. Studies in Educational Evaluation, 64, 100828. https://doi.org/10.1016/j.stueduc.2019.100828

Wanner, T., \& Palmer, E. (2015). Personalising learning: Exploring student and teacher perceptions about flexible learning and assessment in a flipped university course. Computers \& Education, 88, 354-369. https://doi.org/10.1016/j.compedu.2015.07.008

Weinstein, R. S. (2018). On being a pathologist: A pathway to pathology practice; the added value of supplemental vocational training and mentoring in college and medical school. Human Pathology, 82, 10-19. https://doi.org/10.1016/j.humpath.2018.08.035

Wijayanti, A. (2014). Pengembangan Autentic Assesment Berbasis Proyek Dengan Pendekatan Saintifik Untuk Meningkatkan Keterampilan Berpikir Ilmiah Mahasiswa. 7.

Wuli, J. T. R., Susilowati, S. M. E., \& Prasetyo, A. P. B. (2017). The Influence of Self and Peer Assessment on Science Learning. 6.

Yu, F.-Y., \& Wu, W.-S. (2020). Effects of student-generated feedback corresponding to answers to online student-generated questions on learning: What, why, and how? Computers \& Education, 145, 103723. https://doi.org/10.1016/j.compedu.2019.103723 